\title{
Reflective practice in the professional development of working nurses
}

\author{
Refleksyjna praktyka w rozwoju zawodowym pracujących pielęgniarek
}

\section{Tomasz Zdanowicz'1, Tomasz Cuber², Beata Dobrowolska²}

\author{
${ }^{1}$ Klinika Neurologii SPSK Nr 4 w Lublinie/Department of Neurology SPSK Nr 4 in Lublin \\ ${ }^{2}$ Katedra Rozwoju Pielegniarstwa, Wydział Nauk o Zdrowiu \\ Uniwersytet Medyczny w Lublinie/ \\ Chair of Development in Nursing, Faculty of Health Sciences \\ Medical University in Lublin
}

CORRESPONDING AUTHOR/AUTOR DO KORESPONDENCJ:

Tomasz Zdanowicz

Klinika Neurologii, SPSK Nr 4

ul. Jaczewskiego 8, 20-954 Lublin

STRESZCZENIE REFLEKSYJNA PRAKIYKA W ROZWOJU ZAWODOWMM PRACUJACYCH PIELEGNIAREK

Wprowadzenie. Jednym z głównych założeń refleksyjnej praktyki przedstawionej przez Donalda Schöna, obok radzenia sobie w sytuacjach trudnych i nietypowych, było wykorzystanie jej w rozwoju własnej działalności zawodowej.

Cel pracy. Poznanie opinii pielęgniarek na temat koncepcji samorozwoju zawodowego oraz możliwości wykorzystania w tym celu refleksyjnej praktyki.

Materiał i metodyka. Wykorzystano metodę sondażu diagnostycznego z autorskim kwestionariuszem ankiety. Grupa badana liczyła 136 osób (100\%) pielęgniarek i pielęgniarzy pracujących w lubelskich szpitalach.

Wyniki. Zdecydowana większość badanych potwierdziła, że refleksja jest często (44,90\%) i bardzo często (28,70\%) stałym elementem ich rozwoju zawodowego. Większość pielęgniarek $(85,29 \%)$ widzi potrzebę dbania o swój rozwój. Stwierdzono zależność pomiędzy potrzebą dbania o swój rozwój, a wykształceniem ( $\mathrm{p}=0,030)$; zależność pomiędzy potrzebą dbania o swój rozwój, a opinią dotyczącą wypalenia zawodowego $(\mathrm{p}=0,019)$ oraz zależność pomiędzy potrzebą dbania o swój rozwój, a wykorzystywaniem refleksji w praktyce zawodowej $(p=0,005)$.

Wnioski. (1) Zdecydowana większość pielęgniarek widzi potrzebę dbania o swój rozwój zawodowy, jednocześnie pielęgniarki wykorzystujące refleksję w praktyce widzą większą potrzebę w tym zakresie. (2) Pielęgniarki z wyższym wykształceniem częściej uważały, że trzeba dbać o rozwój zawodowy. (3) Pielęgniarki, które w sposób zdecydowany określiły siebie jako niewypalone zawodowo, rozumieją, że rozwój zawodowy jest ważny.

Słowa kluczowe: Refleksyjna praktyka, pielęgniarki, rozwój zawodowy

ABSTRACT REFLECTIVE PRACTICE IN THE PROFESSIONAL DEVELOPMENT OF WORKING NURSES

Introduction. Donald Schön claims that reflective practice is not only about dealing with difficult and untypical situations but also the development of one's professional activity.

Aim of the Study. The aim of the study was to elicit the opinions of nurses about the concept of professional self-development and the possibility of using reflective practice for this purpose.

Material and methods. The diagnostic survey method was used, with the survey questionnaire developed by the authors. The surveyed group consisted of 136 (100\%) nurses working in Lublin.

Results. The majority of study participants stated that reflection was an important part of their professional development (frequent $-44.90 \%$, very frequent $-28.70 \%$ ). Most nurses (85.29\%) regard self-development as important. There was a relationship between caring for one's development and education $(p=0.030)$. There is also a correlation between the need for caring for one's development and the opinion on occupational burnout $(\mathrm{p}=0.019)$.

Conclusions. (1) The majority of the nurses regarded the need to care for their professional development as important, and the nurses who applied reflection in practice perceived the need as more crucial. (2) The nurses with higher education more often claimed that one should definitely care for his/her development. (3) Nurses who assessed themselves as definitely not burned out understand that professional development is crucial.

Key words: $\quad$ reflective practice, nurses, professional development

\section{INTRODUCTION}

According to Donald Schön, reflective practice is not only about dealing with problematic and untypical situations but it also facilitates one's professional development.
Reflection is a person's ability to consider and analyse their actions, to assess their effectiveness and accuracy, and to draw conclusions [1]. Reflection contributes to gain- 
ing professional experience, which is not equivalent to job seniority, but rather is based on intentional activities aimed at professional development [2]. A reflective practitioner is able to capitalise on his/her experience to gain knowledge which can be used in the future.

\section{MATERIAL AND METHODOLOGY}

The purpose of the research was to get to know the opinions of nurses on the concept of professional selfdevelopment and the possibility of using reflective practice for this purpose. In order to achieve this objective, the diagnostic survey method was used, with the survey questionnaire developed by the authors. The survey was carried out among nurses working in 7 hospitals in Lublin (2 teaching hospitals, 2 ministerial hospitals, 1 district hospitals and 2 regional hospitals). Participation in the survey was completely anonymous and voluntary. The respondents were informed about the purpose of the research and the possibility of discontinuing their participation anytime during the survey. The respondents agreed to participate in the survey. In order to analyse the correlation between variables the chi-square test was used. It was assumed that a significant correlation occurs when $p \leq 0.05$. The analysis was carried out with the use of the SPSS Statistics 19 software for Mac OS X.

\section{RESULTS}

The surveyed group consisted of 136 (100\%) female and male nurses working in hospitals in Lublin. Table 1 contains detailed characteristics of nurses surveyed.

Tab. 1. Description of nurses surveyed

\begin{tabular}{|c|c|c|c|c|c|}
\hline & \multirow{2}{*}{$\%$} & \multirow{2}{*}{$\mathrm{n}$} & \multicolumn{2}{|c|}{ Total } \\
\hline & & & & $\%$ & $\mathrm{n}$ \\
\hline \multirow[t]{2}{*}{ Gender } & Woman & 94,90 & 129 & \multirow{2}{*}{100} & \multirow{2}{*}{136} \\
\hline & Man & 5,10 & 7 & & \\
\hline \multirow[t]{5}{*}{ Age (years) } & $20-25$ & 11,00 & 15 & \multirow{5}{*}{100} & \multirow{5}{*}{136} \\
\hline & $26-35$ & 26,50 & 36 & & \\
\hline & $36-45$ & 31,60 & 43 & & \\
\hline & $45-54$ & 26,50 & 36 & & \\
\hline & 55 and more & 4,40 & 6 & & \\
\hline \multirow[t]{4}{*}{ Level of education } & Secondary & 52,20 & 71 & \multirow{4}{*}{100} & \multirow{4}{*}{136} \\
\hline & Bachelor's degree & 23,53 & 32 & & \\
\hline & Master's degree & 23,53 & 32 & & \\
\hline & $\mathrm{PhD}$ & 0,74 & 1 & & \\
\hline \multirow[t]{4}{*}{ Place of employment } & Medical treatment ward & 45,60 & 62 & \multirow{4}{*}{100} & \multirow{4}{*}{136} \\
\hline & Surgical ward & 25,00 & 34 & & \\
\hline & ICU & 18,40 & 25 & & \\
\hline & $\begin{array}{l}\text { Wards without beds } \\
\text { (e.g. the operating suite, } \\
\text { the radiology unit) }\end{array}$ & 11,00 & 15 & & \\
\hline
\end{tabular}

The nurses were asked how often they intentionally applied reflection in planning and carrying out their professional development. A considerable majority of the surveyed confirmed that reflection was a solid element of their professional development (frequent $-44.90 \%$, very frequent $-28.70 \%$ ). Only $5.10 \%$ of the surveyed never used reflection for this purpose.
The respondents were asked whether it is important to care for one's professional development. Based on the findings, it appears that most nurses $(85.29 \%)$ regard the development as important, with $20.60 \%$ of the surveyed assessing this aspect as definitely important and $64.70 \%$ being less concerned about it. It seems alarming that nearly every 10 th respondent $(9.60 \%)$ thinks that caring for one's development is not necessary. There was a correlation between the need to care for one's development and education $(\mathrm{p}=0.030)$. The nurses with higher education (Bachelor's or Master's degree) were more likely to claim that every professional should care for their development.

There is a correlation between the need for caring for one's development and the opinion on occupational burnout $(p=0.019)$. Nurses who assessed themselves as definitely not burned out saw more sense in caring for their development.

Another correlation was found between the need to be concerned about one's development and applying reflection in professional practice $(\mathrm{p}=0.005)$. Nurses who used reflection in their work definitely saw a purpose in caring for their professional development much more often than other respondents who did not apply reflection.

The nurses were also asked about their approach to acquiring knowledge and new skills from other members of the nursing staff. The analysis of the collected data shows that a considerable majority of the surveyed believes that regardless of age and job seniority, each nurse can participate in the development of their coworkers. Nurses with a lower level of job seniority can share the knowledge acquired during their studies, while nurses with more practice can share their experience. The answer was selected by as many as $94.10 \%$ of the surveyed. In turn, $5.10 \%$ of the respondents claimed that younger nurses should learn from the more experienced ones, and not the opposite. Only $0.70 \%$ of the surveyed saw no point in learning from co-workers.

The surveyed were also asked about their opinions on the most recent scientific findings in the field of nursing. The majority of the respondents $(63.20 \%)$ claimed that they are very important but their use depends on the open attitude of practitioners. $29.40 \%$ of the respondents stated that new scientific findings are essential because they influence the quality of nursing practice. Only $4.40 \%$ of the surveyed believed that results of scientific research are not relevant for nursing because in this field practice departs from theory.

\section{DISCUSSION}

All professionals, nurses included, must constantly care for their professional development. In medical professions, in which scientific development is very dynamic, the personnel should expand their knowledge, improve their skills and apply the so-called reflective practice. In the Polish literature on the issue there are no studies on reflective practice, which translates into a low awareness among nurses of the possibilities of applying this tool.

In the United Kingdom reflective practice has become part of nursing education, scientific research and clinical 
activity itself. Reflection and reflective practice are presented in English-language literature as part of professional development, leading to growing self-awareness and understanding, promoting critical thinking and combining theory with practice [3]. Ruth-Sahd [4] mentions the benefits of applying reflection, including, among others, combining theory and practice, learning from one's experience, developing critical thinking and the ability to assess uncertain and complex situations. In turn, Cooney [5] claims that reflection is a tool which facilitates learning through finding strong and weak points. Reflection in nursing is also the professional development of expertise, developing skills and validating knowledge. Of particular importance is the ability to analyse an action and an attempt to gain access to the knowledge on which it was based. According to Seed [6], reflection makes it possible to access the knowledge which was needed in a given action. Analysis may be useful in solving similar problems in the future. It can also contribute to the certainty with which some actions are performed with a complete confidence in their fairness and legitimacy. Thus, reflection cannot replace knowledge based on scientific evidence but it coexists with such knowledge.

Writing about reflection, Clarke [7] points out that it contributes to understanding the practical value of theory. Reflection facilitates using the acquired knowledge in practice. This is particularly crucial during studies and specialty training when nurses acquire new knowledge. As claimed by Plack and Santasier [8], reflection enables nursing students and practitioners to find potential solutions to problems which may arise in the future. Cooperation between experienced nurses and their younger co-workers is important. The former can help trainees understand difficult situations and see the problem from a different perspective. A reverse situation is also possible, when nurses who have recently finished their studies or specialty training share their knowledge on the newest scientific findings with other members of the nursing staff. Unfortunately, as the authors' research demonstrates, there is still a small group of nurses who think that only young nurses can learn from their more experienced co-workers.
The law requires nurses to permanently upgrade their professional skills. Reflection-based development is a similar issue. This view is emphasized by Rolfe [9], who claims that reflection cannot stop at any point and there is no peak of professional development for nurses. He claims that nurses who have fallen into the standard routine (meaning that they have ceased to develop) are at a high risk of experiencing an occupational burnout. They have a certain amount of knowledge and skills but when facing a problem exceeding the way they perceive their work, they usually adjust the problem to their perception. This is why constant development, as well as analysing one's actions, finding deficiencies in one's knowledge and supplementing them are so important

In the practical use of reflection, Gibb's cycle may prove useful. It consists of 6 phases. The first one is the description of the event. A nurse should answer the question: "What happened?" In the next phase, thoughts and feelings associated with the event are analyzed, which is aimed at recognizing the motivations of actions and disrupting factors. Due to the above, in the third phase a nurse is able to consider the positive and negative aspects of the event, and move to the stage of analysis, in which the undertaken action is confronted with the nurse's knowledge, possibly based on literature. In the next phase, i.e. conclusion, the nurse attempts to answer the question what else s/he could do. The last phase is creating an action plan to provide for possible future events of this kind $[10,11]$.

\section{CONCLUSIONS}

1. A considerable majority of the nurses regarded professional development important and the nurses who applied reflection in practice perceived the need as more crucial.

2. The nurses who received higher education (i.e. Bachelor's or Master's degree), were more likely to present a positive opinion about professional development.

3. For nurses claiming that they have not experienced professional burnout, professional development is crucial.

\section{Refleksyjna praktyka w rozwoju zawodowym pracujących pielęgniarek}

\section{WPROWADZENIE}

Jednym z głównych założeń refleksyjnej praktyki przedstawionej przez Donalda Schöna, obok radzenia sobie w sytuacjach trudnych i nietypowych, było wykorzystanie jej w rozwoju własnej działalności zawodowej. Refleksja pozwala spojrzeć na realizowane przez siebie działania, dokonać analizy, ocenić ich skuteczność, poprawność oraz wyciągnąć wnioski [1]. Zastosowanie refleksji przyczynia się do zdobywania doświadczenia zawodowego, które nie jest tożsame ze stażem pracy, ale buduje się właśnie przez świadome działania na rzecz rozwoju zawodowego [2]. Refleksyjny praktyk to osoba potrafiąca przełożyć zdobyte doświadczenia na świadomą wiedzę, z której można skorzystać w przyszłości.

\section{MATERIAŁ I METODYKA}

Celem badań było poznanie opinii pielęgniarek na temat koncepcji samorozwoju zawodowego oraz możliwości wykorzystania w tym celu refleksyjnej praktyki. Dla realizacji celu wykorzystano metodę sondażu dia- 
gnostycznego i posłużono się samodzielnie opracowanym kwestionariuszem ankiety. Badania przeprowadzono wśród pielęgniarek pracujących w 7 szpitalach w Lublinie ( 2 szpitale kliniczne, 2 szpitale resortowe, 1 szpital powiatowy i 2 szpitale wojewódzkie). Udział w badaniach był całkowicie anonimowy i dobrowolny. Respondenci zostali poinformowani o celu badań oraz o tym, iż mogą wycofać się z udziału w badaniach w każdym momencie jego trwania. Osoby badane wyraziły zgodę na udział w badaniach. Do sprawdzenia zależności pomiędzy zmiennymi wykorzystano test chi-kwadrat. Przyjęto, że istotna zależność zachodzi jeśli $\mathrm{p} \leq 0,05$. Do analizy wykorzystano program SPSS Statistics 19 w wersji dla systemu Mac OS X.

\section{WYNIKI}

Grupa badana liczyła 136 osób (100\%) pielęgniarek i pielęgniarzy pracujących w lubelskich szpitalach. Szczegółowe dane socjodemograficze zawarto w tabeli nr 1 .

\section{Tab. 1. Charakterystyka badanej grupy}

\begin{tabular}{|c|c|c|c|c|c|}
\hline & \multirow{2}{*}{$\%$} & \multirow{2}{*}{$\mathrm{n}$} & \multicolumn{2}{|c|}{ Suma } \\
\hline & & & & $\%$ & $\mathrm{n}$ \\
\hline \multirow[t]{2}{*}{ Płeć } & Kobiety & 94,90 & 129 & \multirow{2}{*}{100} & \multirow{2}{*}{136} \\
\hline & Mężczyźni & 5,10 & 7 & & \\
\hline \multirow{5}{*}{$\begin{array}{l}\text { Wiek } \\
\text { (w latach) }\end{array}$} & $20-25$ & 11,00 & 15 & \multirow{5}{*}{100} & \multirow{5}{*}{136} \\
\hline & $26-35$ & 26,50 & 36 & & \\
\hline & $36-45$ & 31,60 & 43 & & \\
\hline & $45-54$ & 26,50 & 36 & & \\
\hline & 55 i więcej & 4,40 & 6 & & \\
\hline \multirow[t]{4}{*}{ Wykształcenie } & Średnie & 52,20 & 71 & \multirow{4}{*}{100} & \multirow{4}{*}{136} \\
\hline & wyższe $\left.\right|^{0}$ & 23,53 & 32 & & \\
\hline & wyższe $\|^{\circ}$ & 23,53 & 32 & & \\
\hline & wyższe III0 & 0,74 & 1 & & \\
\hline \multirow[t]{4}{*}{ Miejsce pracy - oddział } & zachowawczy & 45,60 & 62 & \multirow{4}{*}{100} & \multirow{4}{*}{136} \\
\hline & zabiegowy & 25,00 & 34 & & \\
\hline & intensywnej terapii & 18,40 & 25 & & \\
\hline & bezłóżkowy & 11,00 & 15 & & \\
\hline
\end{tabular}

Pielęgniarki zostały zapytane o częstość wykorzystywania świadomej refleksji w planowaniu i realizowaniu własnego rozwoju zawodowego. Zdecydowana większość badanych potwierdziła, że refleksja jest często $(44,90 \%)$ i bardzo często $(28,70 \%)$ stałym elementem ich rozwoju zawodowego. Tylko $5,10 \%$ badanych nigdy nie wykorzystuje refleksji w tym celu.

Osoby badane zapytano o opinię na temat potrzeby dbania o swój rozwój zawodowy. Na podstawie uzyskanych danych można stwierdzić, że większość pielęgniarek $(85,29 \%)$ widzi potrzebę dbania o swój rozwój, przy czym $20,60 \%$ badanych określa tę potrzebę jako zdecydowaną, natomiast $64,70 \%$ jest mniej co do tego przekonana. Niepokojący może być fakt, że blisko co 10 ankietowany $(9,60 \%)$ uważa, iż raczej nie ma potrzeby dbania o swój rozwój. Stwierdzono zależność pomiędzy potrzebą dbania o swój rozwój, a wykształceniem $(\mathrm{p}=0,030)$. Pielęgniarki z wyższym wykształceniem, zarówno I jak i II stopnia, częściej uważały, że o rozwój trzeba dbać zdecydowanie, aniżeli pielęgniarki ze średnim wykształceniem.

Istnieje także zależność pomiędzy potrzebą dbania o swój rozwój, a opinią dotyczącą wypalenia zawodowego $(\mathrm{p}=0,019)$. Pielęgniarki, które zdecydowanie określiły się jako niewypalone zawodowo, widzą większą potrzebę dbania o swój rozwój.

Wykazano również zależność pomiędzy potrzebą dbania o swój rozwój, a wykorzystywaniem refleksji w praktyce zawodowej $(\mathrm{p}=0,005)$. Pielęgniarki stosujące refleksję w swojej pracy widzą zdecydowaną potrzebę dbania o swój rozwój zawodowy znacznie częściej niż ich koleżanki nie stosujące refleksji.

Pielęgniarki zostały zapytanie również o podejście do czerpania wiedzy i nauki nowych umiejętności od koleżanek z zespołu pielęgniarskiego. $\mathrm{Z}$ analizy uzyskanych danych wyraźnie wynika, że zdecydowana większość badanych uważa, iż niezależnie od wieku i stażu pracy, każda pielęgniarka może coś wnieść do rozwoju koleżanek. Młodsze stażem pielęgniarki wiedzę zdobytą w czasie studiów, natomiast starsze - swoje doświadczenie. Odpowiedź taką wskazało aż 94,10\% badanych. Z kolei 5,10\% respondentów było zdania, że tylko młodsze pielęgniarki powinny uczyć się od starszych. Tylko $0,70 \%$ osoba uznała, iż uczenie się od koleżanek nie ma sensu.

Badanych zapytano także o opinię na temat znaczenia nowości naukowych w dziedzinie pielęgniarstwa. Większość badanych $(63,20 \%)$ było zdania, że są one bardzo ważne, ale ich zastosowanie zależy od otwartości praktyków. 29,40\% respondentów, uważa nowinki naukowe za bardzo ważne, gdyż te przekładają się na jakość pielęgnowania. Tylko $4,40 \%$ badanych było zdania, że wyniki badań naukowych w dziedzinie pielęgniarstwa nie mają zastosowania, gdyż teoria rozmija się z praktyką.

\section{DYSKUSJA}

Profesjonalista, jakim niewątpliwie jest pielęgniarka, musi nieustannie dbać o swój rozwój zawodowy. W przypadku zawodów medycznych, gdzie rozwój nauki jest bardzo dynamiczny, powinno się to dokonywać poprzez poszerzanie swojej wiedzy, doskonalenie umiejętności oraz tzw. refleksyjną praktykę. W polskiej literaturze brakuje badań na temat refleksyjnej praktyki, co przekłada się na niską świadomość pielęgniarek na temat możliwości tego narzędzia.

W Wielkiej Brytanii refleksyjna praktyka stała się częścią edukacji pielęgniarek, badań naukowych, jak również samej aktywności klinicznej. Refleksja i refleksyjna praktyka jest przedstawiana w literaturze anglojęzycznej jako mająca zastosowanie w profesjonalnym rozwoju, prowadząca do zwiększenia samoświadomości i zrozumienia, promująca krytyczne myślenie, czy wreszcie łącząca teorię z praktyką [3]. Ruth-Sahd [4] wymienia korzyści płynące ze stosowania refleksji, zaliczając do nich powiązanie teorii z praktyką, uczenie się z własnych doświadczeń, rozwój krytycznego myślenia oraz oceny niepewnej i złożonej sytuacji. Z kolei Cooney [5] uważa, że refleksja jest narzędziem, które pozwala na naukę poprzez znalezienie słabych i mocnych stron. Refleksja w pielęgniarstwie to także profesjonalny rozwój biegłości, poszerzanie kompetencji oraz walidacja wiedzy. Szczególne znaczenie ma umiejętność przeanalizowania działania i próba odkrycia wiedzy jaka leżała u jego podstaw. Według Seed [6] reflek- 
sja umożliwia odnalezienie wiedzy jaka była potrzebna w danym działaniu. Analiza może pomóc w rozwiązywaniu podobnych problemów w przyszłości. Może także zamienić niepewne działania w działania wykonywane z pełnym przekonaniem o ich słuszności. Refleksja nie zastępuje więc wiedzy popartej dowodami naukowi, ale współistnieje razem $\mathrm{z}$ nią.

W swoich rozważaniach na temat refleksji Clarke [7] zauważa, że refleksja przyczynia się do zrozumienia praktycznej wartości teorii. Pomaga wykorzystać poznaną wiedzę w praktyce. Jest to istotne zwłaszcza na etapie studiów czy specjalizacji, kiedy pielęgniarka zdobywa nową wiedzę. Według Plack i Santasier [8] refleksja pozwala studentom i adeptom zawodu na znajdowanie potencjalnych rozwiązań problemów, jakie mogą napotkać w przyszłości. Istotna jest współpraca starszych pielęgniarek z uczącymi się koleżankami. Doświadczone pielęgniarki mogą pomóc zrozumieć młodym adeptkom zawodu trudne sytuacje. Mogą przyczynić się do spojrzenia na daną sprawę $\mathrm{z}$ innego punktu widzenia. Możliwa jest także odwrotna sytuacja, kiedy pielęgniarki kończące studia, czy specjalizacje przekazują nowinki naukowe pozostałym członkom zespołu pielęgniarskiego. Niestety, jak pokazały badania własne, cały czas istnieje niewielka grupa pielęgniarek, które uważają, że tylko młodsze pielęgniarki moga nauczyć się czegoś od starszych koleżanek.

Ustawowo rozumiany rozwój zawodowy pielęgniarek powinien być ciągły, tak jak ciągły jest rozwój nauk medycznych. Podobnie jest $\mathrm{z}$ rozwojem opartym na refleksji. Podkreśla to Rolfe [9] twierdząc, że nie ma momentu, w którym refleksja może zostać zakończona, a pielęgniarka znajduje się na najwyższym poziomie rozwoju zawodowego. Uważa on, że pielęgniarka, która popadła w rutynę i przestała się rozwijać, bardzo szybko może ulec wypaleniu zawodowemu. Posiada ona pewien zasób wiedzy oraz umiejętności, jednak jeśli w swojej praktyce napotka problem, który wychodzi poza ramy, przez jakie postrzega swoją pracę, może dostosować ten problem do własnego postrzegania. Dlatego tak ważne jest nieustanne stosowanie refleksji, analizowanie swoich działań, określanie niedoborów swojej wiedzy oraz jej uzupełnianie.

W praktycznym stosowaniu refleksji pomocny może być cykl Gibbsa. Składa się on z 6 faz. Pierwsza $z$ nich to opis zdarzenia. Pielęgniarka musi sobie odpowiedzieć na pytanie: Co się wydarzyło? W kolejnej fazie należy przeanalizować odczucia i myśli związane z tym wydarzeniem, co pozwala poznać motywy i podstawy działania oraz czynniki, które je zakłócały. Dzięki temu w trzecim etapie pielęgniarka ma możliwość zastanowienia się nad dobrymi i złymi stronami wydarzenia. Pozwoli to przejść do etapu analizy, w której dochodzi do konfrontacji podjętego działania z posiadaną wiedzą. Jest to także czas na ewentualne sięgnięcie do literatury. W następnym etapie, którym jest konkluzja, pielęgniarka szuka odpowiedzi na pytanie, czy mogła zrobić coś jeszcze. Ostatnia faza, to stworzenie planu działania, jeśli dojdzie do takiego zdarzenia w przyszłości $[10,11]$.

\section{WNIOSKI}

1. Zdecydowana większość pielęgniarek widzi potrzebę dbania o swój rozwój zawodowy, jednocześnie pielęgniarki wykorzystujące refleksję w praktyce widzą większą potrzebę w tym zakresie.

2. Pielęgniarki z wyższym wykształceniem, zarówno I jak i II stopnia, częściej uważały, że zdecydowanie trzeba dbać o rozwój zawodowy.

3. Pielęgniarki, które w sposób zdecydowany określiły siebie jako niewypalone zawodowo, rozumieją, że rozwój zawodowy jest ważny.

\section{PIŚMIENNICTWO/REFERENCES}

1. Schön D. The Reflective Practicioner. How professionals think in action. Basic Books; 1983.

2. Benner P. From Novice to Expert. Addison-Wesley, C.A; 1984.

3. Cotton AH. Private thoughts in public spheres: issues in reflection and reflective practices in nursing. Journal of Advanced Nursing. 2001.36 (4): 512-519.

4. Ruth-Sahd L. Reflective Practice: A Critical Analysis of Data-Based Studies and Implications for Nursing Education. Journal of Nursing Education. 2003. 42(11): 488497.

5. Cooney A. Reflection demystified: answering some common questions. British Journal of Nursing. 1999. 8, (22): 1530-1534.

6. Seed J. Reflection on action: communication is the key. Journal of Perioperative Practice. 2006. 16, (12).

7. Clarke M. Action and reflection: practice and theory in nursing. Journal of Advanced Nursing. 1986. 11: 3-11.

8. Plack M, Santasier A. Reflective Pratice: A Model for Facilitating Critical Thinking Skills Within an Integrative Case Study Classroom Experience. Journal of Physical Therapy Education. 2004. 18, (1): 4-12.

9. Rolfe G. Beyond expertise: theory, practice and the reflexive practitioner. Journal of Clinical Nursing. 1997. 6: 93-97.

10. Gibbs, G. Learning by Doing: A guide to teaching and learning methods. Further Education Unit, Oxford Brookes University, 0xford, 1988.

11. http://www.cumbria.ac.uk/Public/LISS/Documents/skillsatcumbria/ ReflectiveCycleGibbs.pdf (dostęp: 28.01.2015)

Tłumaczenie/Translation: Agnieszka Ochniowska-Fior

Praca przyjęta do druku/Manuscript received:

06.07.2015

Praca zaakceptowana do druku/Manuscript accepted: 05.08.2015 